\title{
Mineralogical Variation of the Banks of Shatt Al-Arab and Shatt Al-Basrah River Sediments in Southern Iraq
}

\author{
Amna N. Al-Amery ${ }^{1, *}$ and Harith A. Al-Saad ${ }^{1}$ \\ Department of Geology, College of Science, Basrah University, Basrah, Iraq \\ Correspondence: amna.geo10@gmail.com
}

\begin{abstract}
Received:

21 August 2021

The sediments on the banks of Shatt al-Arab and Shatt Al-Basrah have been studied to find

Accepted:

5 November 2021 out their mineralogical variation. Twenty-two samples were collected from depths of $20 \mathrm{~cm}$ of recent sediments Shatt Al-Arab and Shatt Al-Basrah Rivers banks, with approximately equal distances between them, the grain size analysis was conducted, and selected samples were prepared for X-ray diffraction, heavy and light minerals analysis. The result of grain size

Published:

31 January 2022 analysis showed that silt loam texture is dominated in Shatt Al-Arab River while silty clay loam texture in Shatt Al-Basrah River. quartz, calcite, dolomite, feldspar, and halite represent the light minerals in the silt fraction in the study area sediments, while the clay minerals are represented by kaolinite, palygorskite, illite, and montmorillonite-chlorite in Shatt Al-Arab River and the same clay minerals with small amount of montmorillonite in Shatt Al-Basrah River. The petrographic analysis showed that the light mineral contents in the sand fraction are composed primarily of quartz, feldspar, and rock fragment. The main rock fragments consist of carbonate, chert igneous and metamorphic rocks, mudstone, and evaporates (Gypsum). The heavy minerals contents are opaque minerals, pyroxene, hornblende, chlorite, biotite muscovite, epidote, staurolite, kyanite, garnet, tourmaline, rutile, and zircon.
\end{abstract}

Keywords: Grain size analysis; Mineralogy; Clay minerals; Heavy minerals; Light minerals; Basrah rivers

\section{Introduction}

Shatt Al-Arab River (East of Basrah Governorate) formed by the confluence of Tigris and Euphrates Rivers in Al-Qurna town northern Basrah Governorate in the south of Iraq and it continues to flow southeast until it reaches the Arabian Gulf, the Shatt Al-Arab river length from Qurna to its mouth is about $192 \mathrm{~km}$, and its width varies between 250 meters at Qurna area, and about 750 meters at its mouth in Rass Al-Bisha area (Rahi, 2018). Shatt Al-Basrah Canal (west of Basrah Governorate) represents an artificial waterway that connects the southern marshes with the northern parts of the Arabian Gulf via Khor Al-Zubair area. (Hassan, et al., 2018) The length of the canal is $37 \mathrm{~km}$, its average width is 59 meters and its depth ranges between 5-7 meters (Naser et al., 2010 in Amaal et al., 2021). It is a canal alternative to Shatt al-Arab River, which was built to reduce floods and drain excess water during flood seasons (Al-Aesawi et al., 2013)

The study area is located in Basrah, Governorate Eastern-South part of Iraq and is restricted between longitudes $\left(47^{\circ} 77^{\prime} 29^{\prime \prime}-47^{\circ} 80^{\prime} 73^{\prime \prime} \mathrm{E}\right)$ and latitudes $\left(30^{\circ} 58^{\prime} 60^{\prime \prime}-30^{\circ} 34^{\prime} 39^{\prime \prime} \mathrm{N}\right)$. Shat Al-Arab and Shatt Al-Basrah Rivers are sited within the Mesopotamian plain, which occupies the middle and

DOI: $10.46717 /$ igj.55.1A.9Ms-2022-01-28 
southern parts of the Mesopotamia foredeep within the Iraqi territory. It is a significant basin of alluvial sediments that accumulate in the quaternary period and a movable basin contains evidence pointing to its recent tectonic activity (Fouad and Sissakian, 2011) (Fig.1)

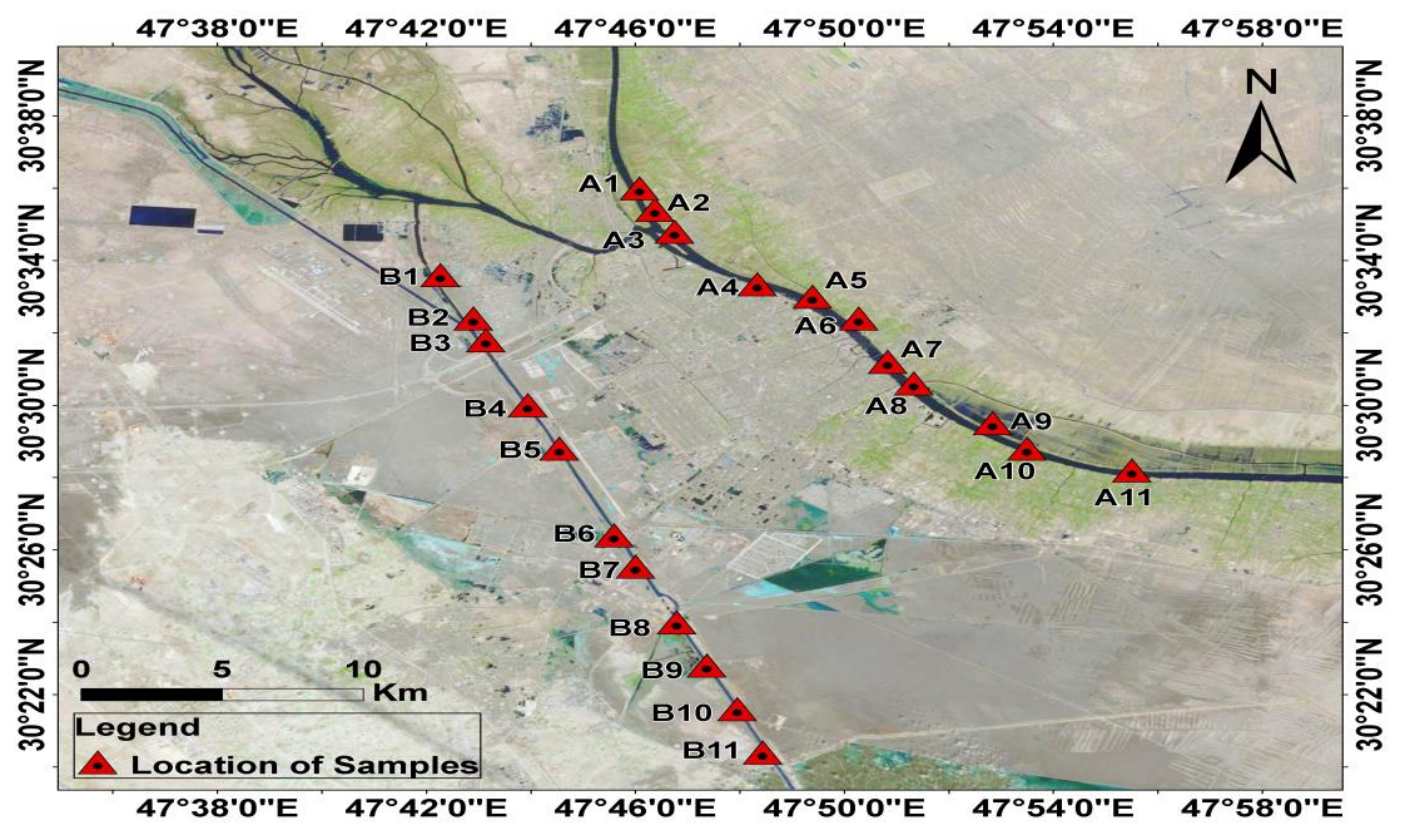

Fig.1. A map of the study area showing the locations of the sediment samples

The flood plain of the Shatt Al-Arab River is made up of silty clay and clay sediments while, downstream from Basrah, Shatt Al-Arab River has received and continues to receive its sedimentary load from the Karun River that comes from Iranian lands. The sediment changes from silty mud around Basrah into brown muddy sand downstream from their confluence near Al-Siba area (Sissakian et al., 2020). There are many previous studies about the study area, including Al-Hamad (2017) which studied the sedimentological, mineralogical, and fossils of the Shatt Al-Arab River and showed that calcite, quartz, dolomite, and feldspar are the major dominant light minerals while kaolinite, illite, chlorite, palygorskite, and mixed-layer of montmorillonite- chlorite are the major clay minerals that present in the study area. Sedkhan (2009) studied the sedimentary and mineral properties of the Karun river area conference with the Shatt Al-Arab River and found that the opaque minerals are dominant nearby the confluence area, followed by pyroxene, amphibole, epidote, garnet, celestite, biotite, chlorite, tourmaline, staurolite, zircon and alteration mineral. The light minerals are quartz, chert, feldspar, and the clay minerals are kaolinite, illite, chlorite. (Albadran et al., 1996) studied the distribution of heavy minerals in the low part of the Shatt al Arab River and showed that the coarse fraction of the recent sediments in this area mostly consists of light minerals with very few percentages of heavy minerals. The light minerals are composed of calcite and quartz while the heavy minerals fall into four groups, arranged in descending order of frequency: opaque, metastable, mica, and ultrastable groups. (Hassan, 2007) presented a geochemical and hydrological study of the sediments of the Shatt Al-Arab River to provide information about the movement of the distribution of trace elements in these sediments. The results indicated that the Shatt Al-Arab sediments suffer from high contamination of $\mathrm{Pb}$ and $\mathrm{Cd}$ elements, while the degree of contamination was moderate with $\mathrm{Cu}, \mathrm{Zn}, \mathrm{Mn}$, and $\mathrm{Fe}$ elements. (Al-Janabi et al., 2019) studied the heavy metals (Cd, Cr, Mn, and Fe) in the Shatt Al-Basrah sediments; the work revealed that there was Fe pollution in the sediments of the Shatt Al-Basrah canal, as indicated by the pollution index, and Ca had a high Enrichment Factor in all positions. Al-Jaberi et al. (2016) studied heavy metals pollution and sediments quality of Shatt Al-Arab River; the study found that Cr, 
$\mathrm{Ni}, \mathrm{Mo}, \mathrm{Zn}$, and $\mathrm{Cu}$ concentrations were heavy to moderately polluted, whereas $\mathrm{Pb}$ was unpolluted at all of the selected sites. Shakir et al. (2016) studied the metal distribution in Shatt Al-Basrah sediments to characterize the geochemistry of four heavy minerals $(\mathrm{Cu}, \mathrm{Ni}, \mathrm{Pb}$, and $\mathrm{Zn})$ in sediments and showed that the concentration of the metal was homogeneous and within acceptable limits during the study. The most important aim of the study is to determine the mineralogical composition of the sediments clay minerals, light minerals, and heavy minerals and the variation in these mineral components along the banks of the Shatt Al-Arab and Shatt Al-Basrah Rivers.

\section{Materials and Methods}

\subsection{Field work}

Field work was carried out during two trips, on 15 and 29 October 2020., where a complete survey of the study area was conducted. Twenty-three samples were collected from depths of $20 \mathrm{~cm}$ of recent sediments from the banks of the Shatt al-Arab and Shatt Al-Basrah Rivers, with approximately equal distances between them (Table 1 and Fig.1), and placed in plastic bags, then transported to the laboratory to prepare them for laboratory work.

Table 1. Sites for taking river sediment samples in the study area

\begin{tabular}{lll}
\hline Samples number & \multicolumn{2}{c}{ Coordinates } \\
\hline A1 & $47^{\circ} 46^{\prime} 22^{\prime \prime} \mathrm{E}$ & $30^{\circ} 35^{\prime} 24^{\prime \prime} \mathrm{N}$ \\
A2 & $47^{\circ} 46^{\prime} 04^{\prime \prime} \mathrm{E}$ & $30^{\circ} 36^{\prime} 00^{\prime \prime} \mathrm{N}$ \\
A3 & $47^{\circ} 46^{\prime} 44^{\prime \prime} \mathrm{E}$ & $30^{\circ} 34^{\prime} 48^{\prime \prime} \mathrm{N}$ \\
A4 & $47^{\circ} 48^{\prime} 52^{\prime \prime} \mathrm{E}$ & $30^{\circ} 33^{\prime} 00^{\prime \prime} \mathrm{N}$ \\
A5 & $47^{\circ} 49^{\prime} 23^{\prime \prime} \mathrm{E}$ & $30^{\circ} 33^{\prime} 00^{\prime \prime} \mathrm{N}$ \\
A6 & $47^{\circ} 50^{\prime} 16^{\prime \prime} \mathrm{E}$ & $30^{\circ} 32^{\prime} 24^{\prime \prime} \mathrm{N}$ \\
A7 & $47^{\circ} 50^{\prime} 49^{\prime \prime} \mathrm{E}$ & $30^{\circ} 31^{\prime} 12^{\prime \prime} \mathrm{N}$ \\
A8 & $47^{\circ} 51^{\prime} 19^{\prime \prime} \mathrm{E}$ & $30^{\circ} 30^{\prime} 36^{\prime \prime} \mathrm{N}$ \\
A9 & $47^{\circ} 53^{\prime} 16^{\prime \prime} \mathrm{E}$ & $30^{\circ} 29^{\prime} 24^{\prime \prime} \mathrm{N}$ \\
A10 & $47^{\circ} 53^{\prime} 29^{\prime \prime} \mathrm{E}$ & $30^{\circ} 28^{\prime} 48^{\prime \prime} \mathrm{N}$ \\
A11 & $47^{\circ} 55^{\prime} 30^{\prime \prime} \mathrm{E}$ & $30^{\circ} 28^{\prime} 12^{\prime \prime} \mathrm{N}$ \\
B1 & $47^{\circ} 42^{\prime} 15^{\prime \prime} \mathrm{E}$ & $30^{\circ} 33^{\prime} 36^{\prime \prime} \mathrm{N}$ \\
B2 & $47^{\circ} 42^{\prime} 53^{\prime \prime} \mathrm{E}$ & $30^{\circ} 32^{\prime} 24^{\prime \prime} \mathrm{N}$ \\
B3 & $47^{\circ} 43^{\prime} 08^{\prime \prime} \mathrm{E}$ & $30^{\circ} 31^{\prime} 48^{\prime \prime} \mathrm{N}$ \\
B4 & $47^{\circ} 43^{\prime} 56^{\prime \prime} \mathrm{E}$ & $30^{\circ} 30^{\prime} 00^{\prime \prime} \mathrm{N}$ \\
B5 & $47^{\circ} 44^{\prime} 32^{\prime \prime} \mathrm{E}$ & $30^{\circ} 28^{\prime} 48^{\prime \prime} \mathrm{N}$ \\
B6 & $47^{\circ} 45^{\prime} 35^{\prime \prime} \mathrm{E}$ & $30^{\circ} 26^{\prime} 24^{\prime \prime} \mathrm{N}$ \\
B7 & $47^{\circ} 46^{\prime} 16^{\prime \prime} \mathrm{E}$ & $30^{\circ} 25^{\prime} 48^{\prime \prime} \mathrm{N}$ \\
B8 & $47^{\circ} 46^{\prime} 47^{\prime \prime} \mathrm{E}$ & $30^{\circ} 23^{\prime} 60^{\prime \prime} \mathrm{N}$ \\
B9 & $47^{\circ} 47^{\prime} 21^{\prime \prime} \mathrm{E}$ & $30^{\circ} 22^{\prime} 48^{\prime \prime} \mathrm{N}$ \\
B10 & $47^{\circ} 47^{\prime} 56^{\prime \prime} \mathrm{E}$ & $30^{\circ} 21^{\prime} 36^{\prime \prime} \mathrm{N}$ \\
B11 & $47^{\circ} 48^{\prime} 26^{\prime \prime} \mathrm{E}$ & $30^{\circ} 20^{\prime} 24^{\prime \prime} \mathrm{N}$ \\
\hline
\end{tabular}

\subsection{Grain Size Analysis}

The grain size analysis was performed using a 63-micron sieve to separate the mud from the sand and the Hydrometer method type (152H, France) for the muddy part in the laboratory of the Geology 
Department, University of Basrah, and according to the British standard specification (B.S1377, 1975), American standard specification (ASTM D4422-63, 2002) and (Folk, 1980).

\subsection{Mineralogical Analysis}

\subsubsection{X-ray diffraction analysis results (XRD)}

Four bulk powdered samples were chosen for determining non-clay minerals and the same samples were used to prepare normal, heating, and ethylene glycol-oriented slides to detect clay minerals; the samples were analyzed by using X-ray diffraction unit type (XRD-6000), SHIMADZU manufacturer company, Japan, the entry voltage is $220 \mathrm{~V} / 50 \mathrm{~Hz}$ in the Ministry of Science and Technology, Department of Research and Materials in Baghdad. The bulk powder samples and the oriented slides were prepared according to (Folk, 1980; Carroll, 1970; Gibbs, 1967; and Gipson, 1966), and scanned in the angle range $2 \theta^{\circ}$ between $\left(2^{\circ}-30^{\circ}\right)$ for non-clay minerals and between $\left(5^{\circ}-30^{\circ}\right)$ for clay minerals. Estimating of approximate proportions of clay minerals of sediments was done by calculating the area under the reflection curve (peak intensity) of the clay mineral (Carver, 1971).

\subsubsection{Heavy and light minerals analysis}

The heavy and light minerals were separated and identified in the Department of Geology, College of Science, University of Baghdad. Fine and very fine sand were separated using heavy liquid (bromoform liquid) with a specific weight of 2.89 (Tucker, 1988; Carver, 1971; Griffiths, 1967; and Müller, 1967) using a binocular microscope and polarizer petrographic microscope.

\section{Results and Discussions}

\subsection{Grain Size Analysis}

The grain size analysis results in the studied samples are given in Tables 2 and 3 which show the percentage of sand silt and clay (Fig. 2 and 3). Silt loam texture is dominated in Shatt Al-Arab River, while silty clay loam texture was dominated in Shatt Al-Basrah River. The fine grain size of sediments could reflect a very low deposit condition (Al-Ali, 2010). The Tigris and Euphrates rivers are the main sources of sediments in the Shatt al-Arab and Shatt Al-Basrah Rivers, as rivers entered marshes, they deposited coarse sediment, whereas finer sediments (silt and clay) reached the Shatt Al-Arab river (Al-Kaaby and Albadran, 2020).

Table 2. Grain size analysis and texture in Shatt Al-Arab river sediments

\begin{tabular}{lcccc}
\hline Sample Number & Sand weight \% & Silt weight \% & Clay weight \% & Texture \\
\hline A1 & 6.49 & 72.51 & 21 & Silt loam \\
A2 & 0.82 & 79.18 & 20 & Silt loam \\
A3 & 7.3 & 65.7 & 27 & Silt loam \\
A4 & 2.45 & 75.55 & 22 & Silt loam \\
A5 & 2.04 & 71.96 & 26 & Silt loam \\
A6 & 2.63 & 73.37 & 24 & Silt loam \\
A7 & 19.75 & 56.25 & 24 & Silt loam \\
A8 & 4.56 & 73.44 & 22 & Silt loam \\
A9 & 37.61 & 48.39 & 14 & Loam \\
A10 & 5.54 & 60.46 & 34 & Silty clay loam \\
A11 & 11.04 & 61.96 & 27 & Silt loam \\
Range & $0.82-37.61$ & $48.39-79.18$ & $14-34$ & \\
Average & 9.11 & 67.16 & 23.72 & \\
\hline
\end{tabular}


Table 3. Grain size analysis and texture in Shatt Al-Basrah river sediments.

\begin{tabular}{lcccc}
\hline Sample Number & Sand weight \% & Silt weight \% & Clay weight \% & Texture \\
\hline B1 & 2.21 & 73.79 & 24 & Silt loam \\
B2 & 20.02 & 69.98 & 10 & Silt loam \\
B3 & 3.26 & 68.74 & 28 & Silty clay loam \\
B4 & 2.31 & 70.69 & 27 & Silt clay loam \\
B5 & 2.85 & 62.15 & 35 & Silty clay loam \\
B6 & 0.53 & 62.47 & 37 & Silty clay loam \\
B7 & 5.22 & 63.78 & 31 & Silty clay loam \\
B8 & 2.56 & 57.44 & 40 & Silty clay loam \\
B9 & 2.39 & 56.61 & 41 & Silty clay \\
B10 & 37.03 & 40.97 & 22 & Loam \\
B11 & 17.6 & 51.4 & 31 & Silty clay loam \\
Range & $0.53-37.03$ & $40.97-73.79$ & $10-41$ & \\
Average & 8.72 & 61.63 & 29.63 & \\
\hline
\end{tabular}

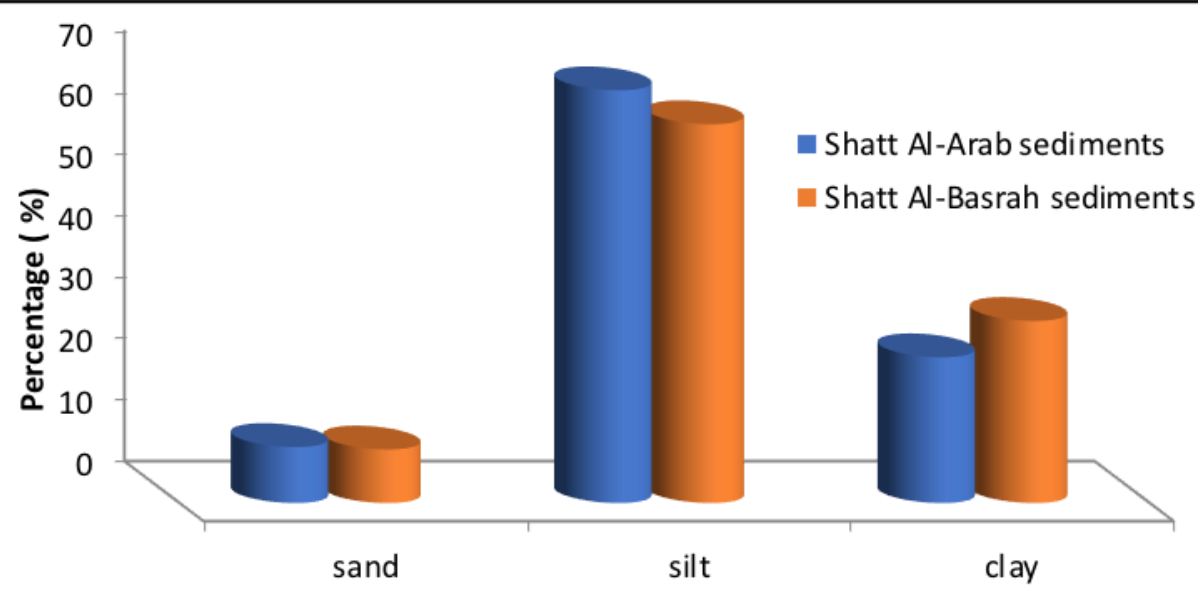

Fig. 2. Average grain size analyses of Shatt Al-Arab and Shatt Al-Basrah river.

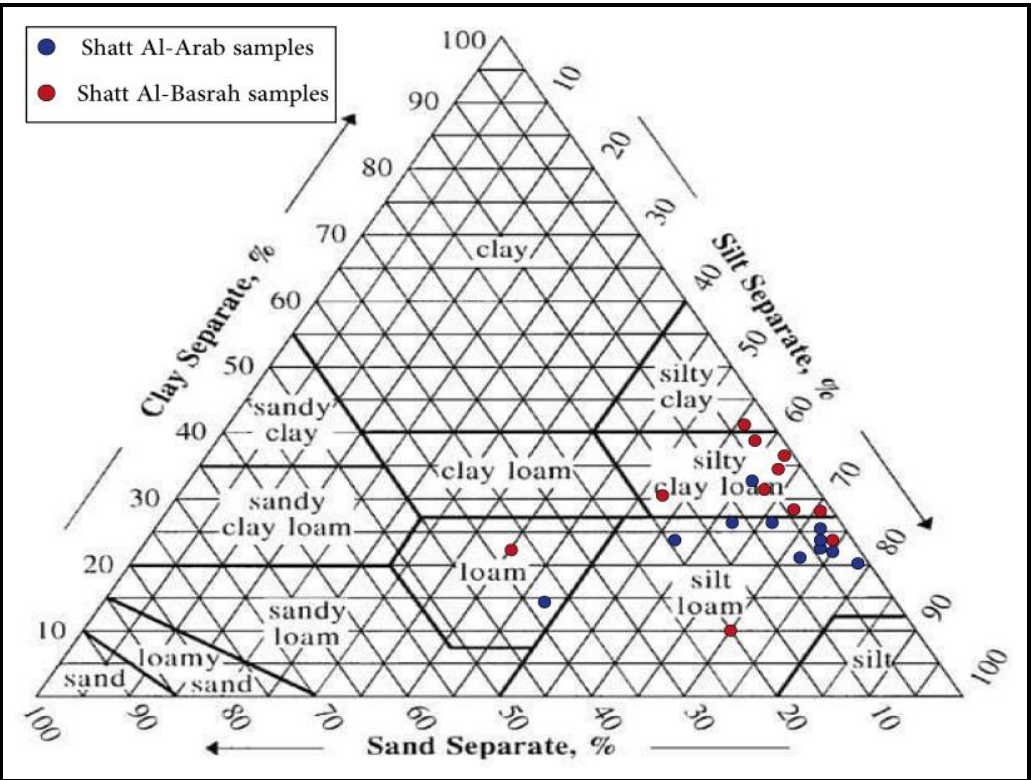

Fig. 3. Sediments texture of the study area according to (Folk, 1980) 


\subsection{Clay Minerals}

Clay minerals are produced and transported on the surface and deep within the Earth's crust through hydrothermal alteration, weathering, sedimentation, pedogenesis, and diagenesis (Austin et al., 2018; Cai et al., 2018). The origin of clay minerals in the study area are detrital, authigenic, and created during the diagenesis process (Al-Ali, 2010). Montmorillonite-chlorite, kaolinite, illite, palygorskite, chlorite, and montmorillonite are the most abundant clay minerals in the study area (Table 4 and Fig. 4).

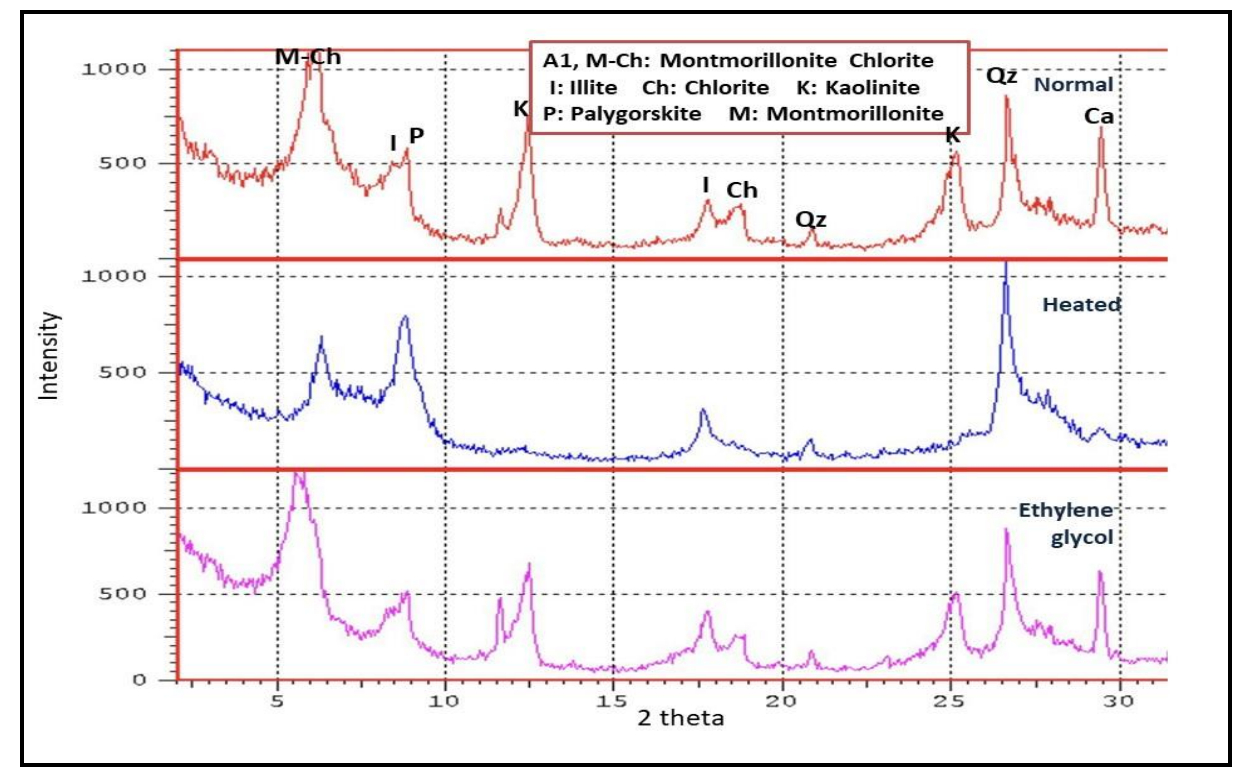

Fig. 4. X-ray Diffraction pattern of the oriented clay minerals in the study area

Montmorillonite-chlorite mixed layers have the highest proportion in the sediments of the study area due to the effect of a diagenetic process. The diagenetic process and the production of mixed-layer clay minerals by stacking layers of different compositions are the main factors of increasing the mixed-layer clay minerals (Meunier, 2005). kaolinite is produced by the dissolution of aluminum and silicon through weathering primary and secondary minerals (Brigatti et al, 2013 and Christidis, 2011). It can form in acidic igneous rocks as a result of the diagenesis of feldspar rich in silica and alumina (Al-Zubaidi, 2004). The origin of kaolinite in the sediments is detrital because the study area could not have a suitable condition to form this mineral. Illite can be found in two forms: in situ in high concentrations of potassium, aluminum, magnesium, iron, sodium, and calcium ions, or as a result of weathering and diagenesis processes on rich potassium igneous rocks. (Weaver, 1969). Alternatively, it can also produce when montmorillonite is illitized in dry-wet climate conditions. (Won et al., 2020). Palygorskite minerals formed as a result of dissolve montmorillonite minerals in an alkaline environment with a content of silica and magnesium (Mackanzie et al., 1981). It has an authigenic origin, the most common origin of palygorskite mineral is authigenic because its inner structure prevents it from being transported over long distances, and marine environments with high rates of temperature, salinity, evaporation, and alkalinity are ideal conditions for forming this mineral in situ (Al-Jaberi, 2015). Chlorite can be obtained as a result of ion exchange with other clay minerals in an iron and magnesium-rich diagenetic fluid environment (Dowey et al., 2012). It notes the absence of the montmorillonite mineral in the sediments of the Shatt al-Arab River and its presence in a small percentage in the sediments of Shatt Al-Basra River with an average of 5.03\%. This may be due to the transformation of montmorillonite to illite by illitization or to chlorite by chloritization or to mixed layer Chlorite-Montmorillonite by the diagenetic process. 
Table 4. Semi-quantitative percentage of clay minerals in the sediment's banks of Shatt Al-Arab and Shatt Al-Basrah

\begin{tabular}{|c|c|c|c|c|c|c|}
\hline Sample & Montmorillonite -chlorite & Kaolinite & Illite & Palygorskite & Chlorite & Montmori-llonite \\
\hline A1 & 40.3 & 26.9 & 14.1 & 12.45 & 6.22 & - \\
\hline A9 & 37.38 & 28.78 & 13.45 & 13.8 & 6.5 & - \\
\hline B1 & 38.77 & 26.73 & 14.7 & 8.77 & 6.53 & 4.48 \\
\hline B10 & 32.35 & 26.47 & 15 & 13.23 & 7.35 & 5.58 \\
\hline Min & 32.35 & 26.47 & 13.45 & 8.77 & 6.22 & 4.48 \\
\hline Max & 40.3 & 28.78 & 15 & 13.8 & 7.35 & 5.58 \\
\hline
\end{tabular}

\subsection{Light Minerals}

Calcite, quartz, dolomite, feldspar, and halite are the common light minerals in the sediments of the study area (Fig. 5), calcite and quartz are the most abundant minerals. Calcite minerals are more abundant in fine and very fine sediments (silt and clay) (Purser and Seibold, 1973). According to Albadran (2006), stated that the carbonate mineral in the Shatt Al-Arab deposits is derived from fauna shells, as well as low Mg calcite and authigenic carbonate. The increase of quartz refers to the highly durable weathering process due to the nature of its chemical bonds, as well as its hardness and lack of cracks, it may be subjected to decomposition in high weathering conditions, especially when the size of its grains is very small (Al-Baghdadi and Al-Abadi, 2021). Furthermore, quartz requires specific temperature, pressure, and time conditions that are not readily available in the soil (Al-Hennawi et al., 2019). The percentage of feldspar mineral is low due to the nonstability of this mineral, so it transformed into clay minerals. The study identified some types of rock fragments in a sand fraction such as sedimentary igneous and metamorphic rock fragments; this demonstrates the diversity of the source rocks of the study area sediments (Al-Kaaby and Albadran, 2020). As well as gypsum can be found in sedimentary rocks, mostly below salt layers, where sulfate salt accumulates before chlorides during the evaporation of seawater or may be formed during the hydration of anhydrite (Al-Busaili and Muzzafar, 1980). Table 5, Fig.6 shows the light minerals in the sand fraction of the sediments of the study area.

Table 5. Light minerals content (\%) in Shatt Al-Arab sediments

\begin{tabular}{lccccc}
\hline Light Components & B1 & B5 & B10 & Range & Avg. \\
\hline Monocrystalline, Quartz & 32.7 & 31.3 & 35.1 & $31.3-35.1$ & 33.0 \\
Polycrystalline, Quartz & 1.3 & 2.5 & 1.7 & $1.3-2.5$ & 1.8 \\
Potash Feldspar, Microcline & 1.9 & 2.0 & 1.2 & $1.2-2.0$ & 1.7 \\
Potash Feldspar, Orthoclase & 4.4 & 3.2 & 4.3 & $3.2-4.4$ & 3.96 \\
Plagioclase, Feldspar & 1.2 & 1.9 & 2.5 & $1.2-2.5$ & 1.86 \\
Carbonate, Rock, Fragments & 31.7 & 32.5 & 35.2 & $31.7-35.2$ & 33.1 \\
Chert, Rock, Fragments & 6.4 & 7.5 & 5.4 & $5.4-7.5$ & 6.4 \\
Igneous, Rock, fragment & 1.7 & 2.4 & 2.1 & $1.7-2.4$ & 2.06 \\
Metamorphic, Rock, Fragments & 2.5 & 3.3 & 3.5 & $2.5-3.5$ & 3.1 \\
Mudstone, Rock, Fragments & 4.5 & 3.7 & 6.1 & $3.7-6.1$ & 4.76 \\
Evaporites (Gypsum) & 7.1 & 6.6 & 8.3 & $6.6-8.3$ & 7.33 \\
Coated Grains by Clay & 2.7 & 3.5 & 3.4 & $2.7-3.5$ & 3.2 \\
Others & 0.9 & 0.6 & 1.2 & $0.6-1.2$ & 0.9 \\
\hline
\end{tabular}




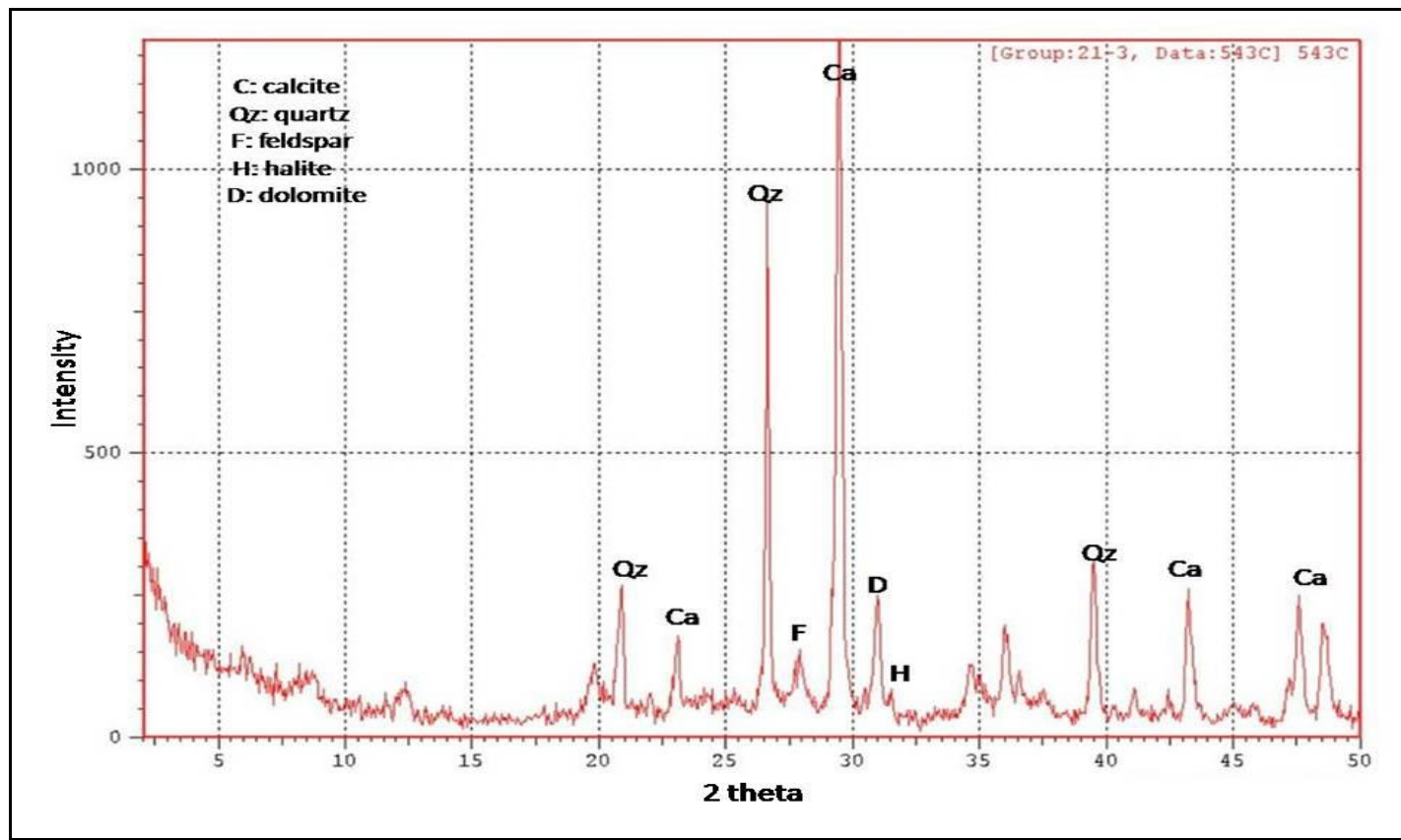

Fig.5. Diffractograms of XRD analysis of bulk samples in the study area
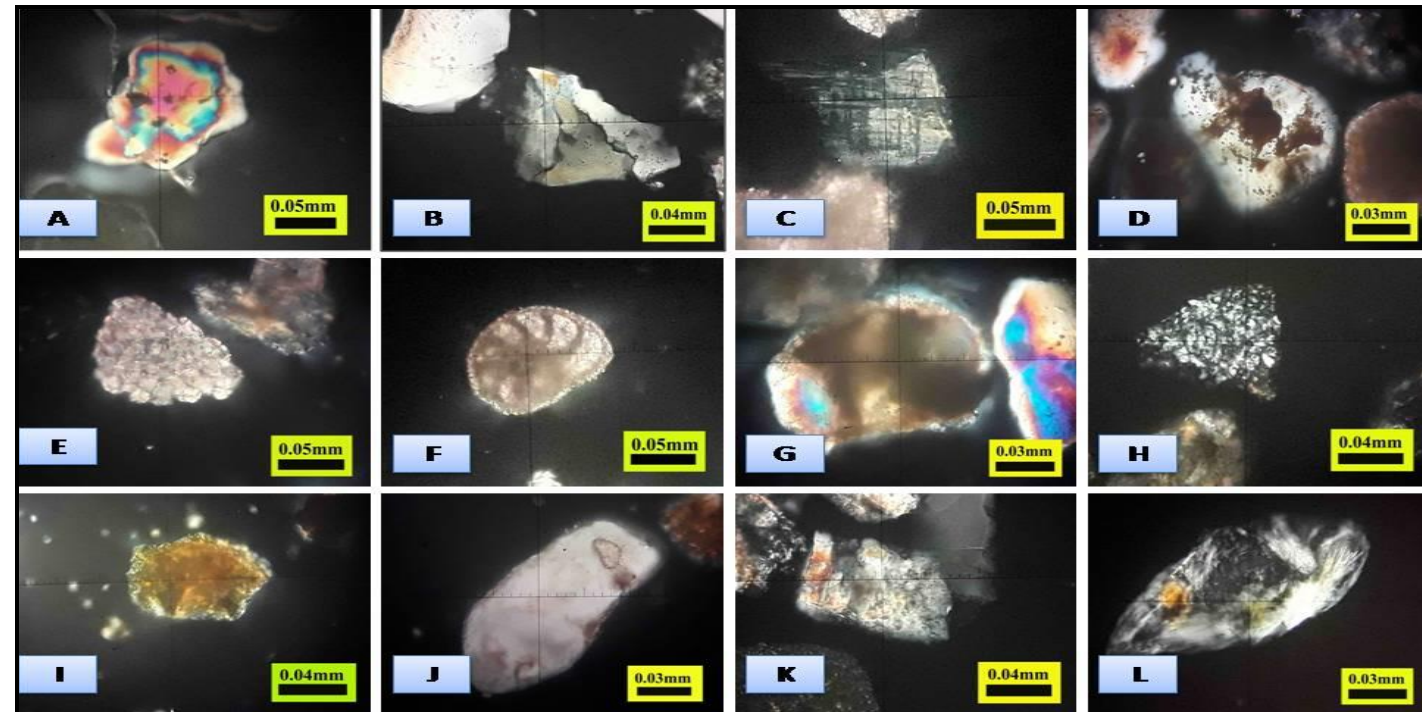

Fig. 6. Types of light minerals in the sand fraction of the sediments of the study area include: (A) Angular monocrystalline quartz, sample number B1, XPL, (B) Angular polycrystalline quartz, sample number A5 XPL, (C) Subrounded microcline, sample number A10, XPL, (D) Sub rounded altered orthoclase, sample number A10, XPL, (E) Angular carbonate rock fragment (Aragonite Shell), sample number B5, XPL., (F) Rounded carbonate rock fragment (fossil grain), sample number B1., (G) grain coated by clay, sample number B1, XPL., (H) Subangular chert rock number B10, XPL.fragment, sample number B10., (I) Subrounded mudstone rock fragment, sample number A1, XPL.(J) Prismatic habit, subhedral evaporate grain (gypsum), sample number A5, XPL., (K) angular plutonic igneous rock, sample number A1, XPL., (L) Subrounded metamorphic rock fragment (schist), sample number A5 XPL.

\subsection{Heavy Minerals}

Tables 6 and 7 and Fig. 7 represent the heavy minerals in the study area. The opaque minerals formed the largest part of the heavy minerals, with a rate of 41.6 in Shatt al-Arab River and (36.77) \% in 
Shatt Al-Basrah River. The source of these minerals is the sediments of the Tigris and Euphrates Rivers due to the abundance of these minerals in each of them and it was confirmed by Philip (1968) when he studied the sediments of the Tigris and Euphrates river, the percentage of opaque minerals is $24.6 \%$, $20.75 \%$ in each of the Tigris and Euphrates rivers, respectively.

Sedkhan (2009) studied the area where the Shatt Al-Arab meets the Karun River northern Basrah and he found that the proportions of opaque minerals are $60.12 \%$. A high percentage of these minerals was acquired by washing the Shatt Al-Arab River sediments because the presence of these minerals in old sediments is less than in recent sediments (Philip, 1968). Ultrastable minerals represented by tourmaline and rutile, are found in a small percentage in the Shatt Al-Arab and Shatt Al-Basrah sediments. Except for zircon, its percentage rises in the sediments of Shatt Al-Basrah as of the Shatt al-Arab most of these minerals come from the Dibdibba Formation sediments, which were transported by the windblown. Most ultrastable minerals in the northwest deposits of the Arabian Gulf come from the Dibdibba Formation, due to the large percentage of ultrastable minerals in the formation and the fact that these minerals emerge from the erosion of old rocks that can last for several sedimentary cycles (Salman and Saadallah, 1988). The presence of ultra-stable minerals indicates that the parents rock is not near and is highly resistant to weathering process (Abas et al., 2019).

Table 6. Heavy minerals content (\%) in Shatt Al-Arab sediments

\begin{tabular}{lccccc}
\hline Heavy minerals & A1 & A5 & A10 & Range & Avg. \\
\hline Opaques & 42.6 & 41.5 & 40.7 & $40.7-42.6$ & 41.6 \\
Chlorite & 7.6 & 8.9 & 5.6 & $5.6-8.9$ & 7.37 \\
Pyroxene & 6.3 & 4.2 & 5.9 & $4.2-6.3$ & 5.47 \\
Hornblende & 4.7 & 6.8 & 5.3 & $4.7-6.8$ & 5.6 \\
Biotite & 5.6 & 4.7 & 5.5 & $4.7-5.6$ & 5.27 \\
Muscovite & 6.5 & 7.6 & 5.3 & $5.3-7.6$ & 6.47 \\
Tourmaline & 2.8 & 2.5 & 2.7 & $2.5-2.8$ & 2.67 \\
Zircon & 6.3 & 4.6 & 5.8 & $4.6-6.3$ & 5.57 \\
Garnet & 4.7 & 4.7 & 5.2 & $4.7-5.2$ & 4.87 \\
Epidote & 5.7 & 6.5 & 4.7 & $4.7-6.5$ & 5.63 \\
Rutile & 3.2 & 2.8 & 3.5 & $2.8-3.5$ & 3.17 \\
Staurolite & 1.8 & 2.9 & 2.5 & $1.8-2.9$ & 2.4 \\
Kyanite & 1.6 & 1.5 & 1.7 & $1.5-1.7$ & 1.6 \\
Others & 0.7 & 0.7 & 0.6 & $0.6-0.7$ & 0.67 \\
\hline
\end{tabular}

Table 7. Heavy minerals content (\%) Shatt Al-Basrah sediments.

\begin{tabular}{lccccc}
\hline Heavy minerals & B1 & B5 & B10 & Min & Avg. \\
\hline Opaques & 35 & 38 & 36.9 & $35-38.4$ & 36.7 \\
Chlorite & 8.4 & 7.5 & 7.8 & $7.5-7.8$ & 7.9 \\
Pyroxene & 4.5 & 6.9 & 5.6 & $4.5-6.9$ & 5.67 \\
Hornblende & 6.6 & 6.6 & 6.5 & $6.5-6.6$ & 6.57 \\
Biotite & 5.2 & 7.5 & 5.2 & $5.2-7.5$ & 5.97 \\
Muscovite & 7.6 & 3.1 & 6.4 & $3.1-7.6$ & 5.7 \\
Tourmaline & 4.1 & 5.2 & 4.1 & $4.1-5.2$ & 4.47 \\
Zircon & 8.5 & 7.8 & 8.5 & $7.8-8.5$ & 8.27 \\
Garnet & 4.9 & 3.5 & 4.6 & $3.5-4.9$ & 4.33 \\
Epidote & 6.5 & 2.2 & 4.2 & $2.2-6.5$ & 4.3 \\
Rutile & 3.8 & 4.2 & 4.9 & $3.8-4.9$ & 4.3 \\
Staurolite & 1.5 & 1.7 & 1.5 & $1.5-1.7$ & 1.57 \\
Kyanite & 2.9 & 1.8 & 2.3 & $1.8-2.9$ & 2.33 \\
Others & 0.5 & 0.6 & 1.5 & $0.5-0.5$ & 0.86 \\
\hline
\end{tabular}



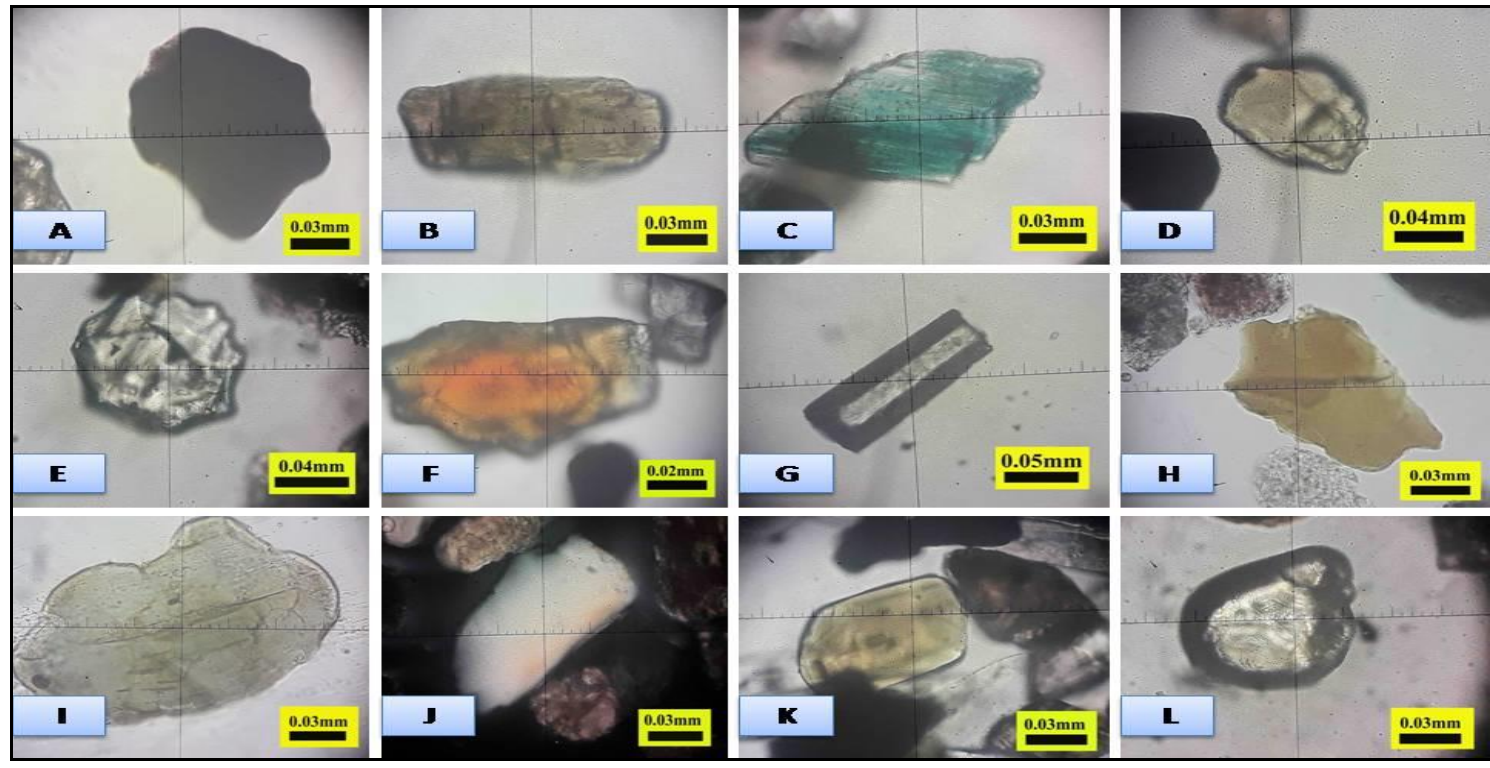

Fig.7. Types of heavy minerals in the sediments of the study area include: (A) Angular opaque grain (Iron oxides), sample number B10, PPL.,(B) High relief, green color, prismatic habit pyroxene, sample number A10, PPL.,(C) High relief, green color hornblende amphibole, sample number A10., (D) Light green color, high relief epidote, sample numberB10 PPL., (E) High relief, equant form, colorless garnet, sample number A10 PPL., (F) High relief, golden color staurolite, sample number A5, PPL.,(G) High relief, colorless, elongated kainite, sample number A1, PPL. (H) Brown color with strong pleochroism flaky form biotite mica, sample number B1 PPL, (I) Flaky form, green color chlorite, sample number A1 PPL., (J) Flaky form, low relief muscovite mica, sample number B10, XPL, (K) High relief, honey color with strong pleochroism tourmaline, sample number B1, PPL, (L) High relief, subrounded, colorless zircon, sample number A5, PPL.

The presence of unstable minerals (pyroxene and hornblende) can indicate the proximity to sediment processing sources (Al-Rawi and Razzak, 2020). These minerals show evidence of rapid erosion and a low rate of chemical degradation (Al-Abadi, 2016). Tigris and Euphrates are regarded as the primary sources of unstable minerals and then distributed in Shatt Al-Arab and Shatt Al-Basrah Rivers sediments (Selman and Saadallah, 1988). Epidote, which is considered a metastable mineral is found in a high percentage in the Shatt Al-Arab and Shatt Al-Basrah Rivers. Albadran et al. (1996) mentioned that the epidote minerals dominate the metastable mineral in the lower part of Shatt Al-Arab that may have come from the Tigris and Euphrates and derived from an older formation. The mica group minerals (chlorite, biotite, and muscovite) are found in the Shatt Al-Arab and Shatt Al-Basrah Rivers.

\section{Conclusions}

Silt loam texture is dominated in Shatt Al-Arab sediments while silty clay loam texture in Shatt Al-Basrah sediments. Quartz, calcite, dolomite, feldspar, and halite represent the light minerals in the silt fraction. The clay minerals are represented by montmorillonite-chlorite, kaolinite, palygorskite, and illite in Shatt Al-Arab sediments and the same clay minerals with a small amount of montmorillonite in Shatt Al-Basrah sediments. Light mineral contents in the sand fraction are composed primarily of quartz, feldspar, and rock fragment, the main rock fragments consist of carbonate, chert, igneous, metamorphic, mudstone, and evaporates (gypsum). The opaque minerals represent the highest proportion of heavy minerals and are followed by pyroxene, hornblende, chlorite, biotite muscovite, epidote, staurolite, kyanite, garnet, tourmaline, rutile, and zircon. The source of the sediments, the Tigris and Euphrates rivers, with little effect of tidal currents on the sediments of the Shatt Al-Basrah River. 


\section{Acknowledgements}

The authors are very grateful to the reviewers, Editor in Chief Prof. Dr. Salih M. Awadh, the Secretary of Journal Mr. Samir R. Hijab, and the Technical Editors for their great efforts and valuable comments.

\section{References}

Abas, N. S., Albedran, B. N., Al-Whaely, U.Q., 2019. Heavy minerals distribution and provenance in palinurus shoal, Northwest of the Arabian Gulf. Basrah Journal of Science., 1, 113-125.

Al-Baghdadi, S. N. S., and Al-Abadi, L. A. S. 2021. Studying and diagnosing the heavy and light sand minerals for some of the soils in southern and northern Iraq. In IOP Conference Series: Earth and Environmental Science,735(1), 012081.

Al-Abadi, L. A. S., 2016. The Effect of the Sedimentation Source on the Mineral and Heavy Elements Properties of Some Soils in Wasit and Maysan Governorates. Ph.D. thesis. Faculty of Agriculture. Baghdad University.

Al-Aesawi, Q. M. F., Abdullah, S. S., Al-Jabbari, M. H. A. 2013. Assessment of hydraulic changes due to construction of a barrage in the Shatt Al-Basrah canal using one-dimension model (Mike 11). Mesopotamian Journal of Marine Science, 28(1), 61-68.

Al-Ali, S.H., 2010. Geochemical and mineralogical study of the fluvial deposits at Abu Al-Khasib area, southeast of Iraq. Mesopotamian Journal of Marine Science, 25(2) 154-165.

Albadran, B., Al-Beyati, F., Abdullah, Y. N., 1996. Heavy minerals distribution in the lower part of the Shatt Al-Arab river, south Iraq. Marina Mesopotamica. 11(1), 17-26.

Albadran, B.N., 2006. Sedimentology and mineralogy of the Al-Hammar Marsh-Southern Iraq: A review. Marsh Bulletin 1(1), 32-39.

Al-Busaili, A.M., Muzaffar M. M., 1980. Minerals and rocks. Ministry of Higher Education and Scientific Research, University of Baghdad.

Al-Hamad, S.S., 2017. Geological of the Shatt Al-Arab River, South of Iraq. M.Sc. thesis, College of Science, University of Basrah.

Al-Hennawi, S., Habib, L., Jaafar, T., 2019. Mineralogical composition of some soils of Swaida Governorate, Syrian Journal of Agricultural Research, 6(1), 261-275.

Al-Jaberi, M. H., 2015. Study of the classics and shells in selected areas at NW of the Arabian Gulf- South Iraq, Scholars Press publish house, Germany, $248 \mathrm{pp}$.

Al-Jaberi, M. H., Al-Dabbas, M. A., Al-Khafaji, R. 2016. Assessment of heavy metals contamination and sediment quality in Shatt Al-Arab River, S Iraq. Iraqi Geological Journal, 88-97.

Al-Janabi, Z. Z., Zaki, S. R., Al-Hassany, J. S., Al-Obaidy, A. H. M., Awad, E., Maktoof, A. A. 2019. Geochemical evaluation of heavy metals $(\mathrm{Cd}, \mathrm{Cr}, \mathrm{Fe}$, and $\mathrm{Mn})$ in sediment of Shatt Al-Basrah, Iraq. Engineering and Technology Journal, 37(2), 237-241.

Al-Kaaby, L. F., Albadran, B. N., 2020. Minerals and sedimentary characteristics of quaternary sediments of different regions in southern Iraq. Iraqi Geological Journal, 53(1A), 68-89.

Al-Rawi, S. A., Razzak, S. K., 2020. Sources of heavy minerals of the Neogene clastic at Bekhme, northern Iraq, Iraqi Journal of Science, 61(10), 2610-2618.

Al-Zubaidi, A. A., 2004, Mineralogical and Geochemical study of Rocks of Injana Formation from Selected Area, Central Iraq, and Assessment of Utilization for Ceramic Industries, Ph.D. thesis, College of Science, University of Baghdad, $31 \mathrm{pp}$.

Amaal, Y. G., Murtada, N. D., Al-Khafaji, K. K. S. 2021. A new record of dotillid crab Ilyoplax stevensi Kemp, 1919 Crustacea: Brachyura: Dotillidae Stimpson, 1858) from Shatt Al-Basrah Canal, Iraq. Ukrainian Journal of Ecology, 11(2), 77-79.

Austin J C, Perry A, Richter D D, Schroeder P A 2018. Modifications of 2:1 clay mineral a kaolinite-dominated ultisol under changing land-use regimes. Clays Clay Miner, 66(1), 61-73.

Brigatti, M. F., Galan, E., Theng, B. K. G., 2013. Structure and mineralogy of clay minerals, Handbook of Clay Science, Elsevier, Oxford, 21-81. 
Cai, J.G., Du, J. Z., Chen, Z. W., Lei, T. Z., Zhu, X. J., 2018. Hydrothermal experiments reveal the influence of organic matter on smectite illitization. Clays Mineralogy, 66(1), 28-42

Carroll, D., 1970, Clay Minerals: A guide to their X-ray identification, Geological Society American, 126, Colorado, 80 .

Carver, R. E., 1971, Petrology of Sediments, John Wiley, New York, 635.

Christidis, G. E., 2011. Advances in the characterization of Industrial Minerals, Mineralogical Society of Great Britain and Ireland, London.

Dowey, P. J., Hodgson, D. M., Worden, R. H., 2012. Pre-requisites, and prediction of chlorite grain coatings in petroleum reservoirs: A review of subsurface examples. Marine and Petroleum Geology, (32), 63-75.

Folk, R.L., 1980. Petrology of Sedimentary Rocks, Hemphill, Austin, 182.

Fouad, S. F., \& Sissakian, V. K., 2011. Tectonic and structural evolution of the Mesopotamia Plain. Iraqi Bulletin Geology. Mining, 4, 33-46.

Gibbs, R.J., 1967. Clay mineral mounting techniques for X-ray diffraction analysis, Notes, California, LOS Angeles, 242-244.

Gipson, M., 1966. Preparation of oriented slides for X-ray analysis of clay minerals, Jounal Sedimentary Petrology, 36, 11-1143.

Griffiths, J. C. 1967. The Scientific Method in the Analysis of Sediments. McCraw-Hill, New York, 508 pp.

Hassan, A. A., Dawood, A. S., Al-Mansori, N. J., 2018. Assessment of water quality of Shatt Al-Basrah canal using water pollution index. International Journal of Engineering and Technology, 7 (4.19), 757-762.

Hassan, W. F., 2007. Geochemical and hydrochemical study of the sediments of the Shatt al-Arab and its contact waters. Unpublished PhD thesis, University of Basra, College of Agriculture, 205 pp.

Mackanzie, R.C., Wilson, M., Mash, A. S., 1981. Origin of palygorskite in some soils of Arabian Peninsula in singer and Galan, E. (eds) palygorskite, sepiolite occurrences genesis and uses development in sedimentology, (37), 77-186.

Meunier, A. 2005. Clays. Springer-Verlag, Berlin, Heidelberg, 472 pp.

Müller, G., 1967. Sedimentary Petrology, Part 1; Methods in Sedimentary Petrology, Translated by Hans Ulrich schmincke, Heffner, 283 pp.

Naser, M., Ali, M., Yasser, A., 2010. New record of the fiddler crab Uca (Paraleptuca) Sinensis (Crustacea: Brachyura: Ocypodidae) from Khor Al- Zubair, Basrah, Iraq. Marine Biodiversity Records, 3, 1-3.

Philip, G., 1968. Mineralogy of recent sediment of Tigris and Euphrates and some of the old detrital deposits. Journal of sedimentary petrology, 38(1), 33-44.

Purser, B.H., Seibold, E., 1973. The principal environmental factors influencing Holocene sedimentation and diagenesis in the Persian Gulf: Holocene carbonate sedimentation and diagenesis in a shallow epicontinental sea,1-9.

Rahi, K. A., 2018. Salinity management in the Shatt Al-Arab River. International Journal of Engineering and Technology, 7 (4.20), 128-133.

Sedkhan, M. T., 2009. Sedimentary, Hydrographic, and Mineralogical study for the Confluence Area of Karun and Shatt al-Arab Rivers and its Surrounded Areas. M.Sc. thesis, College of Science, Basrah University.

Salman, H., Saadallah, A., 1988. Dust fallout in the central and southern part of Iraq. Journal Water Resources. 5(1), 599-621

Shakir, E. M., Al Mashhady, A. A., Al-Janabi, Z. Z., Al-Obaidy, A. H. M., 2016. Geochemical and geo-statistical assessment of heavy metals concentration in the sediment of Shatt Al-Basrah, Iraq. Journal Basic Applied. Resources, 233-239

Sissakian, V. K., Al-Nasari, N., Adamo, N., Abdullah, M., Laue, J., 2020. Stratigraphy of the Mesopotamian Plain: A critical review. Earth Sciences and Geotechnical Engineering, 10 (4), 27-56

Tucker, M. E., 1998. Sedimentary Rocks in the Field. 2nd Ed, John Wiley, and Sons, 155 pp.

Weaver, C.E.,1969. A discussion on the origin of clay minerals of sedimentary rocks, Shell oil company Hauston, Texas, 159-173.

Won, C. D., Hong, H., \& Pak, K. R., 2020. Origin of clay minerals on section of Luochuan loesspalaeosol in Shaanxi Province, northwest China. Frontiers of Earth Science, 14(4), 684-694. 